\title{
ボイラ酸洗における鋼の腐食と防食に関する実験*
}

\section{Experiment on Corrosion and Corrosion Prevention of Steel in Acid Cleaning of Boilers}

坂 本 惊** 小原 倫 德**

Jun Sakamoto and Michinori Ohara

In the cleaning of boilers using an acid solution added with an inhibitor, sometimes occurred considerable corrosion of pinhole-like pitting type. This is largely considered to be due to $\mathrm{Fe}^{3+}$ and $\mathrm{Cu}^{2+}$, in the acid solution formed by the dissolution of scale and corrosion products during acid cleaning.

Laboratory test was carried on the corrosion rate and pitting formation of welded steel specimens immersed in $7 \%$ inhibited hydrochloric acid containing $\mathrm{Fe}^{3+}$ and $\mathrm{Cu}^{2+}$ at $70^{\circ} \mathrm{C}$ for $6 \mathrm{hrs}$, and also

\section{1. 緒}

ボイラの酸洗においてはボイラ材の酸による腐食を防 止するために酸液にインヒビターを添加するのが通常で ある。

しかしインヒビターを添加した酸液を用いた場合でも ボイラ材はピンホール状の孔食を伴う著しい腐食を起す ことがある。このような腐食は，ボイラ内のスケールお よび腐食生成物が酸液に溶解して生じた $\mathrm{Fe}^{3+}$ および $\mathrm{Cu}^{2+}$ に基因するものと考元られ，普通のインヒビター を酸液に添加するだけでは，この腐食を十分抑制するこ とはできない。

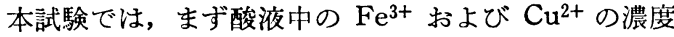
が溶接部を有するボイラ鋼板試験片（以下試験片と略称 する）の腐食隇量および孔食の発生にいかなる影響を与 えるかを調查し，次いでこの腐食を実用上支障のない程 度まで減少させる目的で酸液にインヒビターの外に還元 剂として掹化第一錫を添加した場合の効果を調査した。

試験結果を要約すると，酸液中に $\mathrm{Fe}^{3+}, \mathrm{Cu}^{2+}$ が存在 すると溶接試験片の腐食減量は, これらイオンの濃度に 直線的に比例して増大し，これらイオン濃度の高い場合 はピンホール状孔食が発生するが，酸液に塩化第一錫を 添加することにより腐食減量を大巾に減少し，ピンホー ル状孔食は完全に防止することができた。

な打本試験は三菱三重工技術研究会ボイラ給水委員会 においてボイラの清浄および保存法に関する基準1)を作

* 昭和 35 年 3 月 31 日学振 97 委員会月例会議において発表

** 三菱日本重工業(株)横浜造船所（横浜市西区緑町 3 ) on corrosion preventive effect of stannous chloride added in the same acid solution.

The results are summerized as follows:

(1) When inhibitor alone is used, corrosion rate increases in proportion to the concentration of $\mathrm{Fe}^{3+}$ and $\mathrm{Cu}^{2+}$ and pinhole-like pitting is caused at high concentration of $\mathrm{Fe}^{3+}$ and $\mathrm{Cu}^{2+}$.

(2) Addition of stannous chloride in conjunction with the inhibitor is very effective to reduce the corrosion rate and to prevent the formation of pitting.

成するための基礎実験の一環として行なわれたものであ る。

\section{2. 腐食試験}

\section{（1）試験方法}

第 1 表の $\mathrm{A}, \mathrm{B}$ 系列の溶接板を作成し，これから試

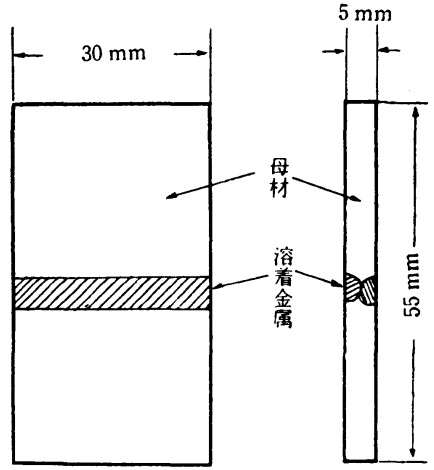

第 1 図試娩片

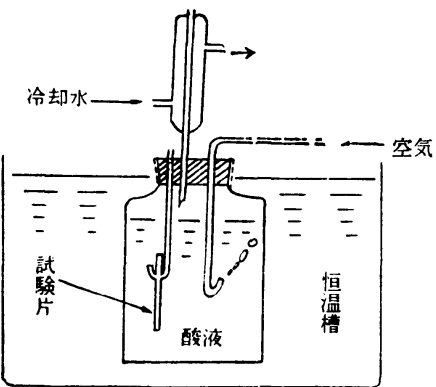

第 2 図腐食試験装置 験片を切り取 り，表面をグ ラインダ研摩 して第 1 図の 寸法に仕上げ た。

腐食試験は 第 2 図の装置 を用い，第 2 表の条件で行 なった。

（2）試験 結果

試験結果を 第 3,4 図に試 験後の試験片 表面状態を写 真 1 3 亿示 于。

全般的傾向 としては，腐 食条件が同一 
第 1 表 溶接試験片系列と溶接方法

\begin{tabular}{|c|c|c|c|c|}
\hline 試験片系列 & ポイラ材 (母材) & 溶接棒 & 溶接方法 & 溶接後の燎鈍 \\
\hline A系列 & \multirow{2}{*}{$\begin{array}{c}\text { JIS G } 3103 \\
\text { SB-46 }\end{array}$} & $\mathrm{BL}-17$ & \multirow{2}{*}{$\begin{array}{l}\text { H型両面 } \\
\text { 手浴接 }\end{array}$} & \multirow{2}{*}{$\begin{array}{c}600 \sim 650^{\circ} \mathrm{C}, \\
1 \mathrm{hr}\end{array}$} \\
\hline B系列 & & BL-70 & & \\
\hline
\end{tabular}

第 2 表 腐食試験条件

\begin{tabular}{|c|c|c|}
\hline 共通条件 & $\begin{array}{l}\text { 酸 液 組 成 } \\
\text { 空気 流 量 } \\
\text { 酸液量/試験片表面積 } \\
\text { 漫 清 条 件 }\end{array}$ & $\begin{array}{l}\mathrm{HCl} 7 \% \text { インヒビター } 0.6 \%(\mathrm{wt} \%) \\
\left.100 \mathrm{cc} / \mathrm{min}^{2}\right) \\
5.5 \mathrm{cc} / \mathrm{cm}^{2} \\
70^{\circ} \mathrm{C}, 6 \mathrm{hr}\end{array}$ \\
\hline 個別条件 & $\begin{array}{l}\text { 酸液に添加した } \\
\text { 祳 }^{2++}, \mathrm{Fe}^{3+}\end{array}$ & $\begin{array}{l}\text { (1) } \mathrm{Cu}^{2+} \text { (単独) } 0 \sim 20,000 \mathrm{ppm} \\
\text { (2) } \mathrm{Fe}^{3+} \text { (単独) } 0 \sim 20,000 \mathrm{ppm} \\
\text { (3) } \mathrm{Cu}^{2+}, \mathrm{Fe}^{3+} \text { (共存) } \\
500 \sim 20,000 \mathrm{ppm} \text { as } \mathrm{Fe}^{3+*}\end{array}$ \\
\hline
\end{tabular}

* as $\mathrm{Fe}^{3+}$ の計算は第 4 表脚注の計算式による。

の場合は試験片の種別（A，B 系列の別）による差は， ほとえど認められない。腐食促進イオン影響では $\mathrm{Cu}^{2+}$ （単独）は同一濃度の $\mathrm{Fe}^{3+}$ (単独) よりも大きい腐食減 量を与えるが，ピンホール状孔食を発生させる作用は母 材に対しては $\mathrm{Cu}^{2+}$ （単独）の方が大きく, 溶着金属部 に対しては $\mathrm{Fe}^{3+}$ (単独) の方が大きい。

\section{(a) 腐食減量}

第 3,4 図の (1)，(2) の $\mathrm{Cu}^{2+}$ (単独) あるいは $\mathrm{Fe}^{3+}$ (単独)の濃度対腐食減量は直線関係を示しており, $\mathrm{Cu}^{2+}$ （単独）は同濃度の $\mathrm{Fe}^{3+}$ (単独) の約 2 倍の腐食減量を 示している。 $\mathrm{Cu}^{2+}$ と $\mathrm{Fe}^{3+}$ 共存の場合の (3) ではその 合計旅度を次の (1) 式により as $\mathrm{Fe}^{3+}$ 濃度と見なし, as $\mathrm{Fe}^{3+}(\mathrm{ppm})$ と腐食減量の関係をプロットした。

$\mathrm{Cu}^{2+}(\mathrm{ppm}) \times 2+\mathrm{Fe}^{3+}(\mathrm{ppm})=$ as $\mathrm{Fe}^{3+}(\mathrm{ppm}) \cdots(1)$

プロットした線は第 3,4 図に示されるように (1), (2) ほど円滑にはなっていないが，(2) の $\mathrm{Fe}^{3+}$ (単独) の 場合の腐食直線に比較的接近しているので (1) 式の as $\mathrm{Fe}^{3+}$ 濃度により腐食減量を推定しても差支えないもの と考觉られる。

\section{(b) ピンホール状孔食}

溶接試験片にピッチングを発生させる酸液中の腐食促 進イオンの最低濃度は第 3 表の通りである。

第 3 表 ピンホール状孔食を発生させる腐食促 進イオンの最低濃度（第 3,4 図参照）

\begin{tabular}{|c|c|c|c|c|}
\hline \multirow{2}{*}{ 腐食促進イオン } & \multicolumn{2}{|c|}{ 母 材 部 } & \multicolumn{2}{|c|}{ 溶着金属 部 } \\
\hline & A 系 列 & B 系 列 & A 系 列 & B 系 列 \\
\hline $\mathrm{Cu}+($ 単独 $)$ & $1,500 \mathrm{ppm}$ & $1,500 \mathrm{ppm}$ & $14,000 \mathrm{ppm}$ & $1,800 \mathrm{ppm}$ \\
\hline $\mathrm{Fe}^{3+\text { (単独) }}$ & $10,000 \mathrm{ppm}$ & $10,000 \mathrm{ppm}$ & $7,000 \mathrm{ppm}$ & $7,000 \mathrm{ppm}$ \\
\hline $\begin{array}{c}\mathbf{C u}^{2}++\mathbf{F e}+ \\
\text { (共存) }\end{array}$ & $\begin{array}{r}8,000 \mathrm{ppm} \\
\text { as } \mathrm{Fe}+\end{array}$ & $\begin{array}{r}8,000 \mathrm{ppm} \\
\text { as } \mathrm{Fe}+\end{array}$ & $\begin{array}{c}7,000 \mathrm{ppm}^{\mathrm{a}} \\
\text { as } \mathrm{Fe}\end{array}$ & $\begin{array}{r}8,000 \mathrm{ppm}^{3} \\
\text { as Fe }\end{array}$ \\
\hline
\end{tabular}

\section{3. 腐食抑制試験}

$\mathrm{Cu}^{2+}, \mathrm{Fe}^{3+}$ が腐食促進イオンとして㗢くのは，これ らイオンが鋼に対して，直接あるいは間接に酸化㓱とし て作用するためであると考え，酸液に還元戍を添加する 方法で腐食抑制試験を行なった。
還元剤としては予備試験に用いた各種還元剂の内で最 も大きい効果を示した $\mathrm{SnCl}_{2}$ を用いた。

\section{(1) 試験方法}

酸液に添加する $\mathrm{SnCl}_{2}$ 添加量は(2),(3)式によって理論 計算される所要量の 1.0 倍, 1.5 倍および 2.0 倍とした。

$\mathrm{SnCl}_{2}$ を添加したこと以外の試験条件は腐食試験の場 合と同じである。

$2 \mathrm{Cu}^{2+}+\mathrm{Sn}^{2+} \rightarrow 2 \mathrm{Cu}^{+}+\mathrm{Sn}^{4+}$

$2 \mathrm{Fe}^{3+}+\mathrm{Sn}^{2+} \rightarrow 2 \mathrm{Fe}^{2+}+\mathrm{Sn}^{4+}$

\section{(2) 試験結果}

試験結果注第 4 表に示す。

第 4 表 腐食抑制試験結果

\begin{tabular}{|c|c|c|c|c|c|}
\hline \multirow{2}{*}{$\begin{array}{c}\mathrm{Cu}^{2+}, \mathrm{Fe}^{3+} \\
\text { 共存濃度 } \\
\left(\text { as } \mathrm{Fe}^{3+}\right)^{*}\end{array}$} & \multirow{2}{*}{ 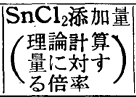 } & \multicolumn{2}{|c|}{ A 系 列 } & \multicolumn{2}{|c|}{ B 系 列 } \\
\hline & & $\begin{array}{c}\text { 腐食减量 } \\
\left(\mathrm{mg} / \mathbf{c m}^{2} \cdot \mathrm{hr}\right)\end{array}$ & $\left|\begin{array}{l}\text { ピツチ } \\
\text { ング }\end{array}\right|$ & $\begin{array}{c}\text { 腐食減量 } \\
\left(\mathrm{mg}^{2} / \mathrm{cm}^{2} \cdot \mathbf{h r}\right)\end{array}$ & 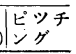 \\
\hline $\begin{array}{r}8,000 \\
8,000 \\
8,000 \\
20,000 \\
20,000 \\
20,000\end{array}$ & $\begin{array}{l}1.0 \text { 倍 } \\
1.5 \text { 倍 } \\
2.0 \text { 倍 } \\
1.0 \\
1.5 \text { 倍 } \\
2.0 \text { 倍 }\end{array}$ & $\begin{array}{l}0.88 \\
0.96 \\
0.41 \\
1.54 \\
1.42 \\
1.06\end{array}$ & $\mid \begin{array}{l}\text { 母材, } \\
\text { 容着金 } \\
\text { 属の6 } \\
\text { 寸れれ } \\
\text { 女登生 } \\
\text { せず }\end{array}$ & $\begin{array}{l}1.01 \\
0.83 \\
0.83 \\
0.99 \\
1.46 \\
1.00\end{array}$ & $\begin{array}{l}\text { 母材, } \\
\text { 溶着金 } \\
\text { 属のW } \\
\text { 夺れに } \\
\text { \&発生 } \\
\text { せず }\end{array}$ \\
\hline
\end{tabular}

* $\mathrm{Fe}^{3+}(\mathrm{ppm}) / \mathrm{Cu}^{2+}(\mathrm{ppm})=10$,

$\mathrm{Cu}_{2}^{2+}(\mathrm{ppm}) \times 2+\mathrm{Fe}^{\wedge}+(\mathrm{ppm})=$ as $\mathrm{Fe}^{3+}(\mathrm{ppm})$

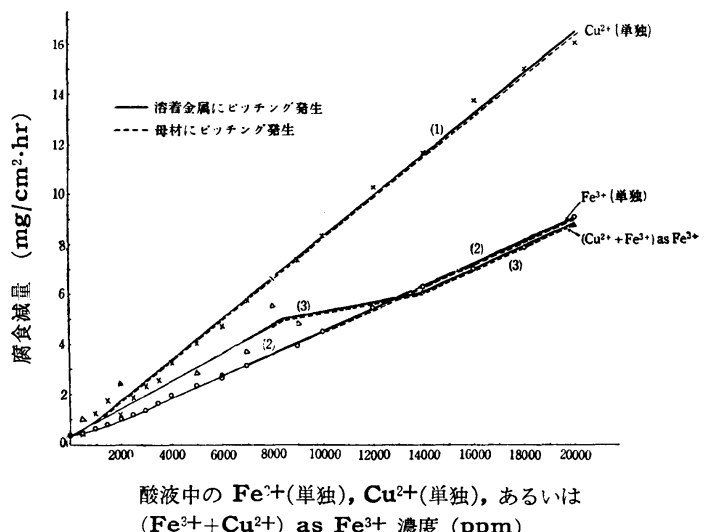

第 3 图酸液中の $\mathrm{Fe}^{3+}, \mathrm{Cu}^{2+}$ 濃度と試験片 （A 系列）の腐食減量の関係

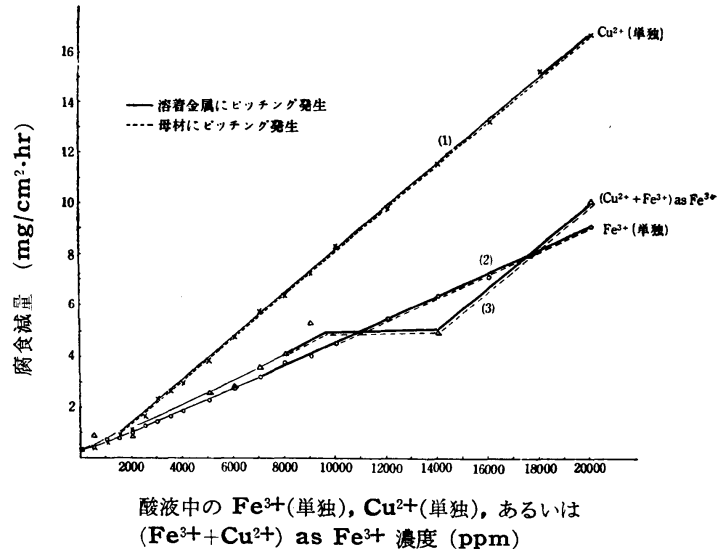

第 4 图 酸液中の $\mathrm{Fe}^{3+}, \mathrm{Cu}^{2+}$ 濃度と試験片 （B 系列）の腐食減量の関係 
$\mathrm{Cu}^{2+}$ 瀑度 $(\mathrm{ppm})$

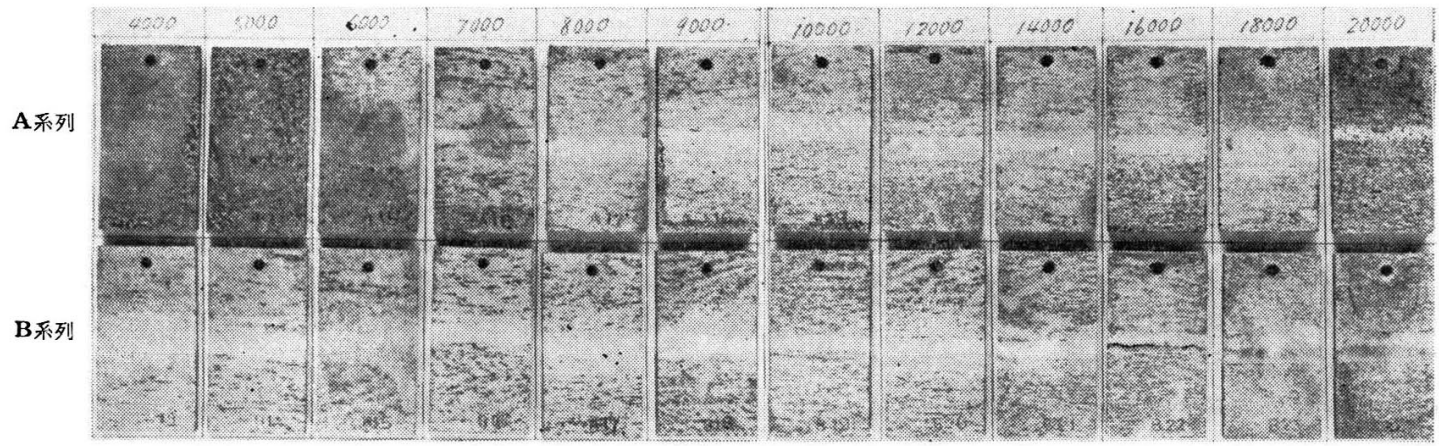

写畺 1 酸液中の $\mathrm{Cu}^{2+}$ (単独) 濃度变化による試験片腐食状況 $\mathrm{Fe}^{3+\cdots}$ 渺度 $\mathrm{ppm}$ )

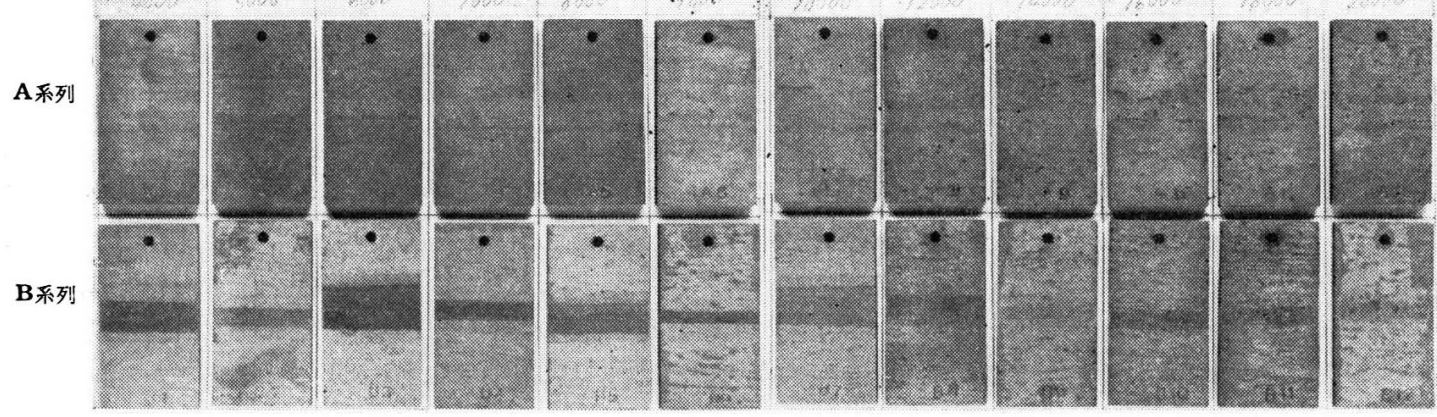

写貪 2 酸液中の $\mathrm{Fe}^{3+}$ (単独) 濃度变化による試験片腐食状況

as $\mathrm{Fe}^{3+}$ 濃度 $(\mathrm{ppm})$

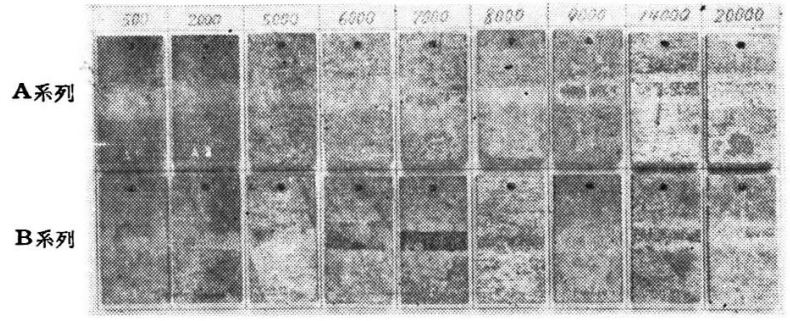

写貪 3 酸液中の as $\mathrm{Fe}^{3+}\left(\mathrm{Cu}^{2+}, \mathrm{Fe}^{3+}\right.$ 共存 $)$ 濃度变化に上る試験片腐食状況

腐食は $\mathrm{SnCl}_{2}$ を添加しない場合に比して著しく防止さ れている。すなわちピンホール状孔食は完全に防止さ れ，腐食減量は 8,000 ppm as $\mathrm{Fe}^{3+}$ において $\mathrm{SnCl}_{2}$ を 添加しないときの 1/6 1/13(A 系列)，1/4 1/5 (B 系 列)に減少し, 減量絶対量は最高 $1 \mathrm{mg} / \mathrm{cm}^{2} \cdot \mathrm{hr}$ 程度であ る。また 20,000 ppm as $\mathrm{Fe}^{3+}$ においては 1/6〜1/8(A 系列), $1 / 7 \sim 1 / 10$ (B 系列) に減少し, 減量絶対量は最 高 $1.5 \mathrm{mg} / \mathrm{cm}^{2} \cdot \mathrm{hr}$ 程度である。

$\mathrm{SnCl}_{2}$ 添加量は多いほど防食効果は大きい傾向を示し ているが，添加量に比例した効果は表われていない。

\section{4. まとめ}

溶接部を有するボイラ用鋼板試験片に対する $7 \%$ 抑
制熄酸中の $\mathrm{Cu}^{2+}, \mathrm{Fe}^{3+}$ イオンの腐食促進の程度と 腐食防止方法を試験した絬果，

(1) 試験片の腐食減量 は $\mathrm{Cu}^{2+}$ (単独), $\mathrm{Fe}^{3+}$ (単独)イオンの濃度に直線的に比例して増大する。

(2) $\mathrm{Cu}^{2+}$ (単独) は同一濃度の $\mathrm{Fe}^{3+}$ (単独) の場公の約 2 倍の試験片腐食減量を示し, 雨イオン が共存する場合の腐食減量は

$\mathrm{Cu}^{2+}(\mathrm{ppm}) \times 2+\mathrm{Fe}^{3+}(\mathrm{ppm})=$ as $\mathrm{Fe}^{3+}(\mathrm{ppm})$

により計算される as $\mathrm{Fe}^{3+}$ と同濃度の $\mathrm{Fe}^{3+}$ (単独) を含む酸液による腐食減量と等しいものとして差支 えないものと考えられる。

（3）ピンホール状孔食を発生させる傾向は，母材部 に対しては $\mathrm{Cu}^{2+}$ (単独) の方が $\mathrm{Fe}^{3+}$ (単独) より強く, 溶着金属部に対しては, 反対に $\mathrm{Fe}^{3+}$ (単独) の方が, $\mathrm{Cu}^{2+}$ (単独) よりも強い。 $\mathrm{Cu}^{2+}, \mathrm{Fe}^{3+}$ 共存の場合は母 材部および溶着金属部に対して, $\mathrm{Cu}^{2+}$ (単独) と $\mathrm{Fe}^{3+}$ (単独) の場命の中間の強さを示している。

(4) $\mathrm{Cu}^{2+}$ および $\mathrm{Fe}^{3+}$ をそれぞれ $\mathrm{Cu}^{+}$および $\mathrm{Fe}^{2+}$ に還元するために必要な理論計算量の $\mathrm{SnCl}_{2}$ を酸液に 添加することにより，試験片の腐食減量は $\mathrm{SnCl}_{2}$ を添 加しない場合の 1/4 1/13 に減少し, 母材部, 溶着金属 部ともにピンホール状孔食は完全に防止される。 
$\mathrm{SnCl}_{2}$ 添加量を計算量より多くしても，添加量に比例 した防食効果は得られない。(昭和 35 年 5 月 23 日受理)

\section{引用文献}

1) 火力発電, 10, No. 2, 39 (1959)

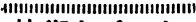

技街トピック

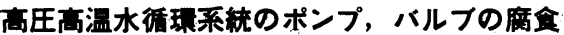

カナダの Shannon Park で民家に熱および熱湯を供 給するのに 125 psi のボイラーを使用している。循環水 ポンプの圧力は $160 \mathrm{psi}$, 温度は $345^{\circ} \mathrm{F}$ である。管路は 鋼管で 3 台の青銅製ポンプおよび約 1,000 個の黄銅製ハ ルブを装備している。ボイラ給水には薬品処理も機械的 脱気方法も論じていないし予熱器も装備していない。

この系統で鋼，ステンレス鋼，銅の部品はほとんど侵 されないが，青銅および黄銅製部品の水速の早い乱流の 多い部分に激しい侵食を生じたので，海軍工廠実験所に 原因の調査と対策の樹立が委嘱された。循環水の $\mathrm{O}_{2}$ お よび $\mathrm{NH}_{3}$ 含量を調査したところ検出されなかった。水 の $\mathrm{pH}$ はカセイソーダの添加によって 10.5〜11で保た れた。このような高温水では $\mathrm{O}_{2}$ の溶解度はきわめて小 さいが，脱気がうまく行なわれないと気泡が水と一諸に 循環して衝撃腐食を起すおとれがある。腐食した扇車と バルブの顕微鏡検査では脱亜鉛現象は見られないがェッ チされたようになっていて結晶粒がはっきり見られた。 扇車用ナットには気泡の衝撃腐食によると思われる孔食 が沢山認められた。衝撃腐食は気泡の衝撃によって金属 の耐食膜が破壊され気泡中の $\mathrm{O}_{2}$ による復極作用のため 腐食を生ずる現象で, 丸味をおびた食孔を生ずる。蒸気 泡の破壊衝撃によるキャビテーションはギザギザの多い 潰食となるので衝撃腐食と区別することができる。海軍
工廠実験所で循環水の $\mathrm{pH}$ を 10 として黄銅と鋼の 試験片の腐食試験を行なったが，約 30 日間の試験で腐 食度はいずれも 0.003 ipy で余り大きくない。鋳鋼の扇 車およびバルプの実地試験を行なった結果, 扇車は 15 力 月後ほとんど異状がなかったが，本体の一部にわずかに キャビテーションによる潰食が見られた。バルブは 6 カ 月経過後全く異状がなかった。青銅製扇車を使用して $\mathrm{pH}$ を 9.5 に低下して実用試験を行なった結果，5 月後には循環水に接触する面には相当の侵食があった が，エッチされたような外観は少なくなり結晶も明らか には見られなかった。侵食は機械的作用によるものと思 われた。近路バルブから冷水を混入して温度を $20^{\circ} \mathrm{F} に$ 低下した場合青銅製扇車は 4 力月経過後以前のようには なはだしく侵されていなかったが, 羽根の内面には軽微 な気泡衝撃腐食が見られた。青銅製および黄銅製部品の 高速水による侵食の原因は気泡による衝撃腐食およびキ ヤビテーションによる潰食である。対策としては, 循環 水系統中の空気の排除を十分に行なうこと, 近路ハシルブ を使用して冷水を混入して循環水の温度を低下しキャビ テーションによる潰食を少なくすること，青銅扇車や黄 銅バルブの使用をやめ鋳鋼製の扇車やバルブを使用する こと等がある。 (E. F.)

J. C. Spurr : Corrosion, 16, No. 5, 9〜12 (1960) May

\section{新刊稆介}

\section{J. H. Morgan: "Cathodic Protection"} $6^{\prime \prime} \times 10^{\prime \prime}, 340$ ページ, 1959,£ 2-17-6（¥3,450)

発行所 Leonard Hill, London 1959

本書は陰極防食法に関し基本的問題から実地の応用ま での広範囲にわたり最近の進歩を包含して取りまとめた もので, 現在においてこの方面の専門書として最も詳細 なものといえよう。次の 11 章よりなっている。

（1）電気化学並びに腐食と陰極防食 （2）陰極防食の 基準（3）電父抵抗と接地抵抗（4）犠牲陽極 （5）外 部電流による防食（6）埋設施設の陰極防食（7）海水 中の陰極防食 （8）電解質使用設供の陰極防食 (9) 迷
走電流および干渉による腐食（10）陰極防食用計器

(11) 陰極防食の経済性

N.P. Fedot'ev \& S. Ya. Grilikhes: “ Electropolishing, Anodizing and Electrolytic Pickling of Metals "”

$51 / 4^{\prime \prime} \times 81 / 4^{\prime \prime} ， 285$ ページ，1960 年 2 月，\$8.40

発行所 Robert Draper Ltd., 85 Udney Park Rd., Teddington, Middlesex, England.

本書はソ連図書（原著者 A. Behr）を翻訳したもので 欧米の業者間で彷来秘密にされていた各種の技術の詳細 を公表している。

(H.S.) 